\title{
Development of Self-Educational Competence of Students by Means of Digital Educational Technologies
}

\author{
Bilyalova A.A. ${ }^{1 *}$ Gilyazeva E.N. ${ }^{1,}$ Polkina G.M. ${ }^{2}$
}

\author{
${ }^{1}$ Kazan Federal University, Naberezhnye Chelny 423800, Russia \\ ${ }^{2}$ Naberezhnye Chelny State Pedagogical University, Naberezhnye Chelny 423800, Russia \\ *Corresponding author. Email: abill71@mail.ru
}

\begin{abstract}
The article is devoted to the urgent problem of the development of self-educational competence of university students by using modern digital educational technologies, namely the Google Classroom Internet platform. Four components of self-educational competence are distinguished: motivational, active, cognitive, evaluative and reflexive. In accordance with these components, levels and tools for determining the development of the self-educational competence of university students through modern digital educational technologies are highlighted. After conducting experimental work with students and analyzing experimental data, which revealed significant differences between students in the control and experimental groups, the authors came to the conclusion that the use of the Google Classroom Internet platform for organizing training positively affects the development of students' self-educational competence.
\end{abstract}

Keywords: competency-based approach, self-educational competence, Google Classroom Internet platform

\section{INTRODUCTION}

The acceptance of the competency-based approach as one of the leading methodological foundations for training specialists predetermined the goals of the educational process in universities in the context of the development of key competencies, which was primarily reflected in the developed third-generation state educational standards. In the educational standards of the third generation, the requirements for the level of mastering the basic educational programs of higher professional education are the graduate's possession of general cultural (universal, subject, basic, key, general) and professional (subjectspecific, subject-specialized) competencies [1]. A significant characteristic of general cultural competencies is self-educational readiness, therefore, there is a need for the development of self-educational competence for all students, regardless of specialty and future profession.

Consequently, the problem of self-development, selfeducation and self-improvement of high school students with professional competence, subject knowledge in their chosen specialty, and developed abilities for independence and creativity becomes an urgent problem.

The development of self-educational competence of students largely depends on the quality application of modern educational technologies. Such educational technologies ensure the readiness of graduates to continuous self-education and to productive, creative activity.

In recent years, in Russia and abroad, there has been a steady trend in the introduction and development of modern digital technologies for the organization of the educational process [2]. One of the tools for introducing such technologies are various services, sites and online platforms. The web platforms Moodle, iSpring, edmodo, Google Classroom service are rapidly gaining popularity, which allow you to create online courses or give tasks for students to work independently with the possibility of feedback [3].

The relevance of the study is due to:

- development of informational technologies in all spheres of human activity, universal digitising and strengthening of digital communication capabilities;

- the need to train a teacher who is able and willing to work in changing conditions, determined by the transformation of society to an information type that involves the use of digital technologies;

- pedagogical expediency of using digital educational platforms and resources for the development of selfeducational competence of future specialists.

\subsection{Related Work}

\subsubsection{Functional and content characteristics of self-educational competence}

In pedagogical literature there is no agreement in views on the meaning and definition of self-educational competence. Moreover the role and activities of the teacher in development of self-educational competence is ambiguously defined. Such methods as method of ongoing monitoring over the course of independent work 
of students, ways of correction, assisting in solving educational and professional tasks are insufficiently developed.

Self-education as a new trend in the modern education system is considered in the works D. Carlson, C. Levy, A.R. Kritskaya, etc. [4-6].

The problem of development of self-educational competence of students is considered in the works De M.Fátima Morgado Cortez Batista, L.G. Elliot, A. Dobrijevic, P. Krstic, R.R. Sagitova, A. Kozerska, etc. [710].

The works of L. Zhimin, P. Fairfield, S. Striguna are devoted to shaping of students ' self-educational activity [11-13].

Self-educational competence is based on the experience of self-educational activities and on the initial desire of a student to expand his educational potential, to increase competitiveness in the labor market. As a result, the role of higher education in the development of the value attitude of graduates to independent activity, and also in the awareness of future specialists of the special importance of self-educational competence for continuous professional and personal development, increases many times.

Self-educational competence as a whole is considered one of the key competencies and is a necessary basis for the successful development of the individual and professional activities of a person.

R.R. Sagitova believes that self-educational competence is a supporting element of the comprehensive development of the individual. It is not connected only with narrow didactic goals but it is more effective if it defines an integrated characteristic that includes a combination of knowledge, skills, methods and experience of selfeducation, as well as personal qualities that are manifested in the need to implement activities aimed at achieving selfrealization of a person [9].

The development of self-educational competence is a process of personal development under the influence of external conditions that continues throughout a person's life and does not have final outlines. However, in contrast to the development of personality, its shaping is realized by the individual and others relatively discretely, since it is associated with the appearance of new, previously absent qualities in the personality structure.

\subsubsection{Analysis of the functionality of the interactive educational platform Google Classroom}

Google Classroom is a free service from Google, developed in 2014 for schools that sought to simplify the teaching process, namely: creating, distributing and evaluating assignments online. It was created as another Google service that can be used for education, as well as the already known Gmail, Docs and Drive. But Google Classroom is ready to provide users with a one-stop solution - by combining quick integration with Google Drive, a user-friendly interface, and new features that educators need. Since 2017, the service is available to all users with a Google account. This service has a large number of advantages.

The interactive educational platform Google Classroom is a convenient and very easy-to-use tool. Using it teachers can easily (with a single" click") provide information to students: texts and / or presentations of lectures, literature for self-study, give tasks for self-study, initiate thematic online discussions, set ratings and make announcements. One of the advantages of Google Class is integration with other Google services: Disk, YouTube, Documents, and Gmail. This allows the teacher to upload information to Google Classroom in almost any format: text, PowerPoint presentations, images, video, audio, and other files.

It is obvious that these features of Google Classroom will contribute to effective learning only if the teacher has a well-thought-out, well-developed course program, as well as texts and / or presentations of lectures, a set of practical tasks that contribute to the assimilation of theoretical material. In other words, Google Classroom in no way replaces the teacher with his didactic skills, but only provides new opportunities for organizing the educational process.

It is worth noting that tasks and work completed by students are stored in an electronic format, organized in the form of a folder structure and documents on Google Drive. All current tasks are displayed on a separate page. Students just need to "click" on the task to start its implementation. Information about completed works is updated in real time. The teacher has the ability to monitor the performance of work, set ratings and add comments. To do this, the teacher must underline or single out only the part of the text that contains the error and leave a comment.

Based on the described above, the Google Classroom application can be used in the University both for lectures (for example, video lectures, seminars for students with the task of commenting or answering content questions), and for practical classes (dictation, translation, essay, tests, presentations, mini -forums on a given topic, implemented using the commenting option).

The choice of this platform is justified by the following features:

1. Class setup. Each class has its own code that students can use to join the community. This process eliminates the need for pre-registries.

2. Integration with Google Drive. When a teacher uses Google Classroom, a folder "Class" is automatically created on their Google Drive with new attachments for each class they create.

3. Organization. When students use Google Classroom, a folder "Class" is created on their Google Drive page with subfolders for each class they join.

4. Automation. When you create an assignment as a Google Doc, the platform will create and distribute individual copies of the document for each student in the class.

5. Timing. When creating a task, the teacher can indicate the deadline for the work. When a student submits a task before the deadline, the status "View" appears on his document, which allows teachers to do the sorting. 
6. Work / Correction. When students have begun their work, the teacher can provide feedback while the student is in the "Viewing" status. When the work is returned to the student, the student again switches to the "Edit" status and continues working on the document.

7. Convenient review. Both teachers and students can see all the tasks on the main Google Classroom screen. This allows controlling the work in several classes at once.

8. Communication. On the main page of the virtual classroom there are links by clicking on which the teacher will be able to create class announcements. During the performance of tasks, it is also possible for the student to contact the teacher (and vice versa) thanks to the integrated possibilities of commenting assignments [14].

\subsection{Our Contribution}

The article discusses the problem of the development of self-educational competence of university students using modern digital educational technologies, namely the Google Classroom Internet platform. Four components of self-educational competence are distinguished: motivational, active, cognitive, evaluative-reflective, and also three levels of its development: low, medium, high. The indicators and tools for determining the development of self-educational competence of university students through modern digital educational technologies are developed. Pilot work was carried out, which consisted in assessing the capabilities of the Internet platform Google Classroom for the shaping of self-educational competence of students.

As a result of the analysis of experimental data, which revealed significant differences between students in the control and experimental groups, the authors conclude that the use of the Internet platform Google Classroom for organizing training has a positive effect on the shaping of students' self-educational competence.

\subsection{Paper Structure}

The rest of the paper is organized as follows. Section 2.1 introduces criteria and levels of development of selfeducational competence, methods for its diagnosis. Section 2.2 is a description of the Pilot work on the development of self-educational competence of students using the Internet platform Google Classroom, and here there is an analysis of the results of the experiment.

Finally, Section 3 concludes the paper.

\section{BACKGROUND}

\subsection{Criteria and levels of development of self- educational competence, methods for its diagnosis}

The study and analysis of psychological and pedagogical literature on the problem of diagnosing the selfeducational competence of the individual showed the absence of uniform criteria for assessing the level of its developing. Some authors $[15,16]$ use the criteria for assessing the developimg of self-educational competence to represent 2 groups of indicators: the integrity criterion for the development of self-educational competence and the productivity criterion for the development of selfeducational competence. The criteria of the first group for the developing of self-educational competence are determined by researchers in accordance with its structural components, the criteria of the second group are the developing of personal motivation for continuous development, satisfaction of graduates with preparation for self-educational activities and employers' satisfaction with the readiness of graduates for self-educational activities. Other authors propose assessing the level of development of self-educational competence by weighting coefficients using the method of expert assessments, as well as applying motivational-value, information-gnostic and activity criteria and their indicators [17]. Common to all researchers is the recognition of the great significance of each component of the structure and its criteria for evaluating such a complex integrative personality profile as self-educational competence. By criteria we understand the signs on the basis of which an assessment is made of the process, subject or phenomenon under study.

Taking into account the above, as a part of selfeducational competence, we can distinguish components of the following types:

Motivational component. It assumes the student's need for self-education, determines a positive attitude and interest in self-educational activities, ensures self-motivation and awareness of both personal and social significance of selfeducational activities.

The activity component. It represents the possession of knowledge and skills to plan, organize and regulate the self-educational process, use modern methods of cognition, apply the results of self-educational activities in specific situations of professional activity.

Cognitive component. It implies the existence of a knowledge system (general, subject and professional).

Evaluation-reflexive component. It lies in the ability of introspection and self-assessment of readiness for selfeducation, adequate assessment of the results of one's selfeducational activity, possession of reflexive technologies in the field of self-educational activity.

It is important to say that all components are in close relationship with each other and a change in one of the components leads to a change in the other. For the successful development of self-educational competence, it 
is necessary to have a system of knowledge (general, subject and professional), skills of self-educational activities, as well as the ability to plan, organize and regulate the self-educational process.

Based on the results of the analysis of special literature, we identified three levels of development of students' selfeducational competence: low level, middle level, high level. Depending on the degree of development of each component, it is possible to determine the level of shaping of self-educational competence of students as a whole.

We managed to assess four pointed above components of self-educational competence: the motivational component, the activity component, cognitive component, evaluationreflexive component.

To assess the level of development of the motivational component, the diagnostic method "Focus on the acquisition of knowledge" developed by E.P. Ilyin and N.A. Kurdyukova was used. The diagnostic method was adapted for university students.

To assess the level of development of the activity component, we invited students to fill out a questionnaire and evaluate their performance on a ten-point scale. This questionnaire made it possible to assess the ability of students to plan and organize self-educational activities.

The level of the cognitive component was studied by the final test in the discipline and analysis of the results of intermediate test and control works. The final test consisted of 30 tasks with the choice of the correct answer out of 4 possible.

When assessing the level of the evaluative-reflective component, a test questionnaire of S. V. Kovalev was used. We used it to determine the level of self-esteem. The points were interpreted as follows: a high level corresponds to a score of 70-50, an average of 50-30 and a low 30-30.

\subsection{Pilot work on the development of self- educational competence of students using the Internet platform Google Classroom}

\subsubsection{The context and methods}

The purpose of the experimental work was to assess the capabilities of the Internet platform Google Classroom for the development of self-educational competence of students of the Department of Philology of the Naberezhnye Chelny Institute of Kazan Federal University. In accordance with the purpose of the study, the following tasks were set: 1 . To carry out a ascertaining stage of the experiment. Its aim was to assess the level of development of self-educational competence of students of the control and experimental groups. 2. To conduct a formative stage of the experiment. Its aim was to introduce the created online educational course on the Internet platform Google Classroom in practical training. 3. To conduct a generalizing stage of the experiment. Its aim was to make control assessment of the level of development of self-educational competence of students with subsequent analysis and processing of the results, drawing conclusions and summarizing. During the experimental work, along with the experiment, such research methods as monitoring students' activities during training, testing, statistical and mathematical processing of the results, analysis and interpretation of the results were used.

A pedagogical experiment was conducted among fourthyear students of the Department of Philology of the Naberezhnye Chelny Institute of Kazan Federal University. The total number of students involved in our pedagogical experiment was 31 people. The number of students in the experimental group was 16 people. The number of students in the control group was 15 people. In the classroom with students of the experimental group, an online training course was implemented on the Internet platform Google Classroom. Students in the control group continued their studies according to the standard traditional program.

Our experiment was divided into three stages: ascertaining, formative and generalizing. The first stage was ascertaining. At this stage of the experiment we studied researches and papers devoted to the problem of development of self-educated competence, also questionnaires and tests were conducted in order to identify students' self-educational competence before the experimental level. The second stage was formative. The purpose of this stage was the implementation of training based on the created educational online course on the Internet platform Google Classroom. The third stage was generalizing. Its purpose was to process the results of testing the online course on the Internet platform Google Classroom.

\subsection{The results of the study and their discussion}

The results are shown in the histograms below (Histograms 1-2). Based on the results of the ascertaining experiment, we revealed the levels of development of each of the four components of the selfeducational competence of students of the experimental and control groups. For the diagnosis of the cognitive component at the stage of the ascertaining experiment, students of both groups were offered entrance testing, which included questions on the permanent

knowledge of previous courses. Analyzing the results of the diagnosis of the cognitive component, we can conclude that in the experimental group, half of the students have an average level of development of this component, the rest have either a low or a high level. In the control group, the situation is similar. We also see a predominantly low level of development of the evaluative-reflective component, both among students of the experimental group and among students in the control group. As for the diagnosis of the motivational component, during the ascertaining experiment, the main motives of students for organizing self-educational activities were identified: career growth, advanced training, maintaining a high level of 
competitiveness. The reasons that complicate the organization of self-educational activities, most students called the lack of free time, laziness, lack of self-discipline and external control.

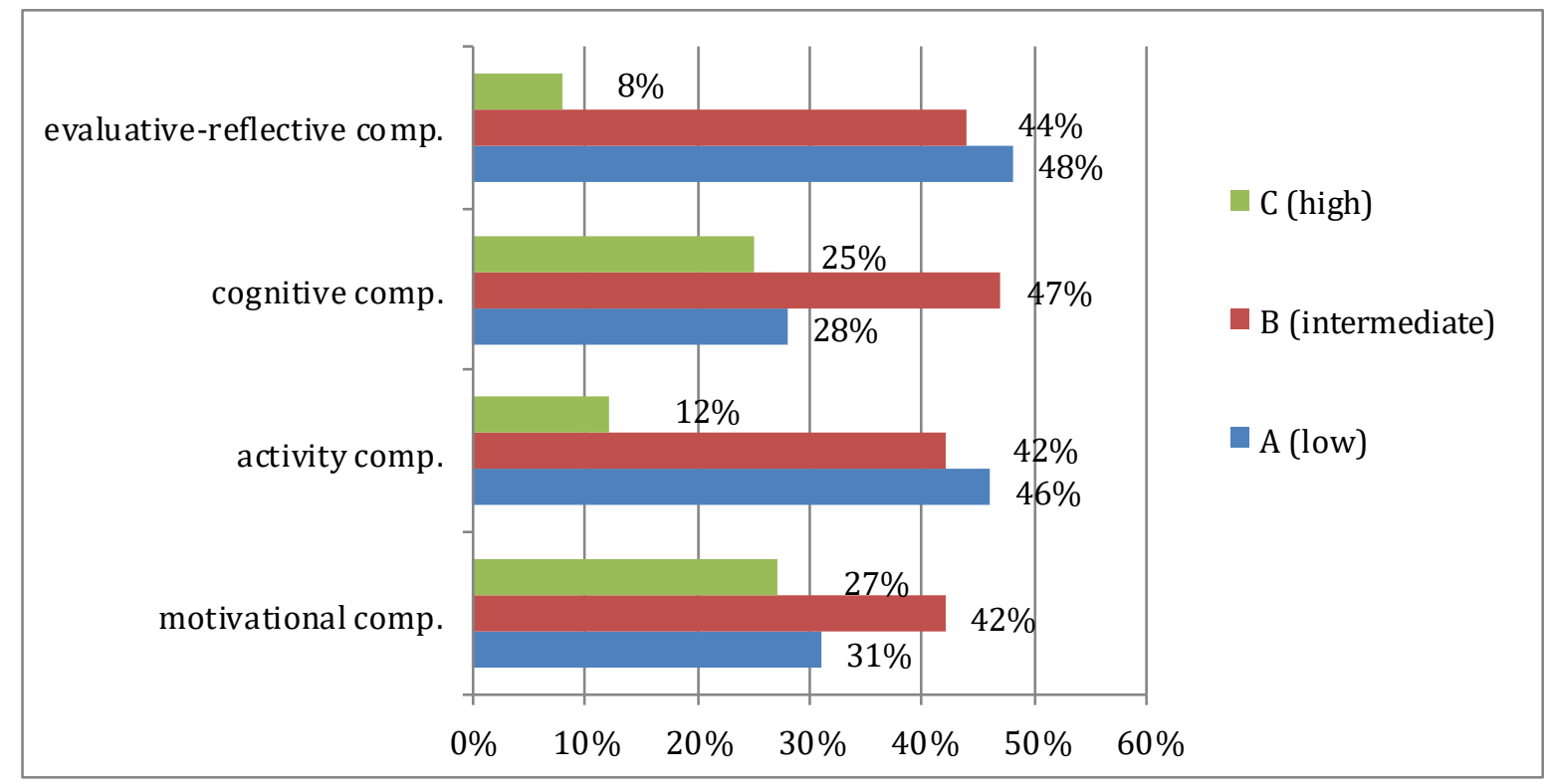

Histogram 1. Initial assessment of the level of development of self-educational competence of students in the control group according to the selected criteria (ascertaining experiment)

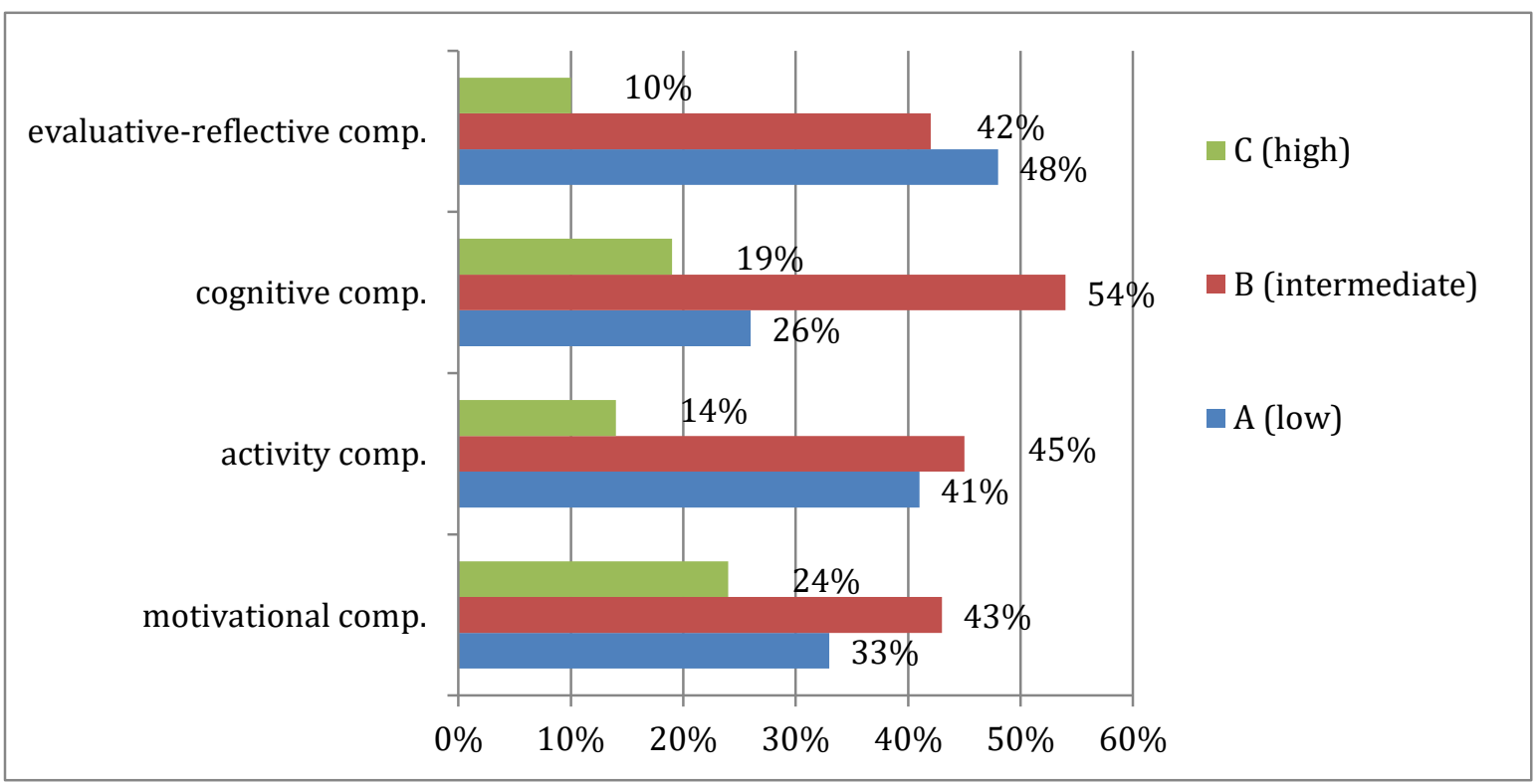

Histogram 2. Initial assessment of the level of development of self-educational competence of students of the experimental group according to the selected criteria (ascertaining experiment)

Analyzing the obtained results, it can be concluded that the level of self-educational competence of students in both the control and experimental groups according to the selected criteria during the ascertaining experiment is 
average for most students, which indicates an insufficient level of self-educational competence of students.

At the formative stage of the pedagogical experiment, the training of the experimental group was carried out on the basis of the online course on the discipline "Workshop on the culture of speech communication of the first foreign language" on the Google Classroom Internet platform.
Training in the control group was conducted in a traditional way, as usual. At the final stage of the experiment, students of the experimental and control groups were diagnosed with the development of the selected components of self-educational competence. The results are shown in the histograms below (Histograms 34).

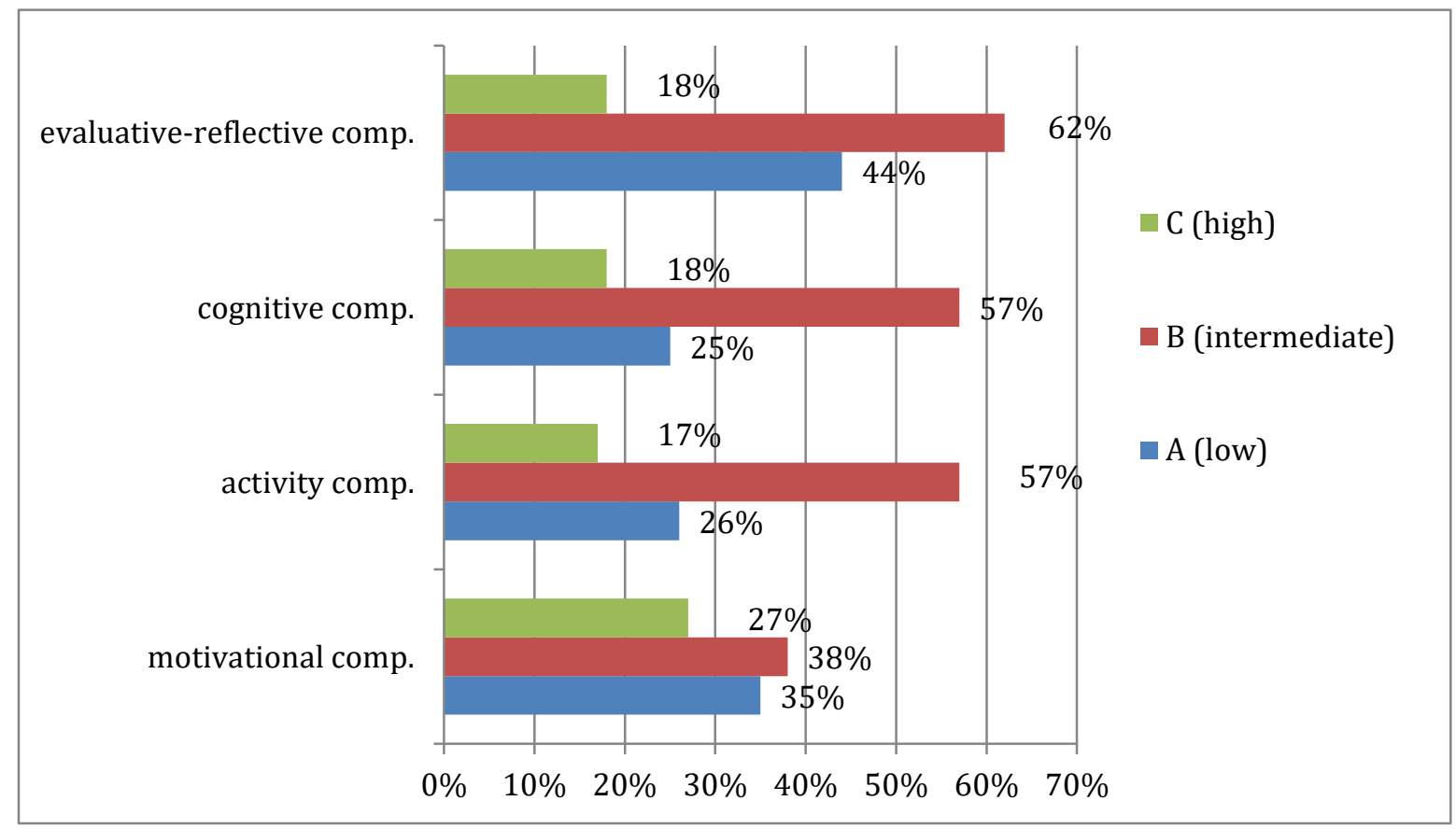

Histogram 3. The final diagnosis of the level of development of self-educational competence of students in the control group according to the selected criteria

evaluative-reflective comp.

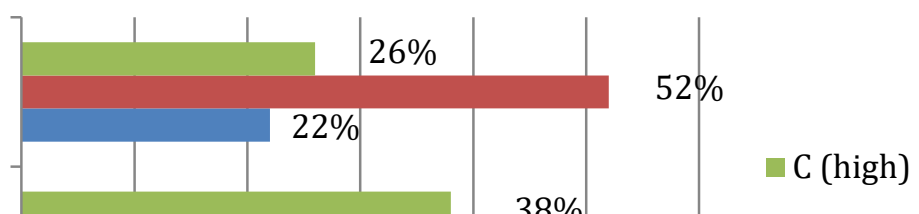

cognitive comp.

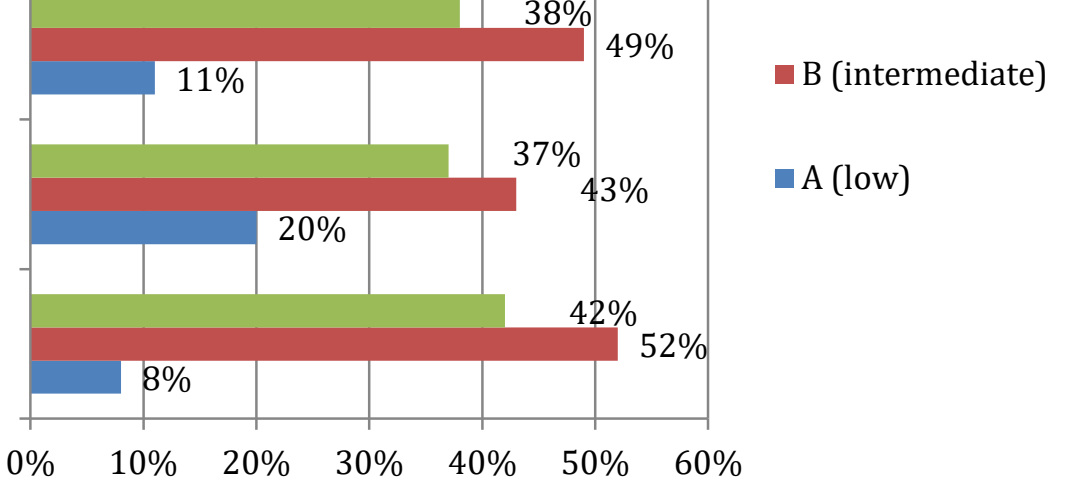

motivational comp.

activity comp.

$-30 \%-40 \%-50 \%-60 \%$

Histogram 4. Final diagnostics of the level of development of skills of self-educational competence of students of the experimental group according to the selected criteria 
From these histograms, we see that the students of the experimental group after the pedagogical experiment increased the level of development of self-educational competence. We got the results: the number of students with a low level in the experimental group decreased from $37 \%$ to $15 \%$, the number of students with an average level in the experimental group changed from $47 \%$ to $49 \%$, the number of students with a high level in the experimental group increased from $17 \%$ to $36 \%$. No significant changes were detected in the control group: a low level decreased by $11 \%$, an average level increased by $10 \%$, a high level increased by $2 \%$.

Therefore, we can conclude that the use of the Internet platform Google Classroom for the organization of training has a positive effect on the development of selfeducational competence of students.

\section{CONCLUSION}

The self-educational competence of students is a complex of four structural components.

Awareness of the value of self-education and the student's readiness for its implementation, the need to achieve personal results through self-educational activities; the predominance of intrinsic motivation, the manifestation of initiative in educational activities, and high activity are characterized by a motivational component.

The knowledge of the educational program material, the ability to freely complete the tasks stipulated by the program, the knowledge system about the methods of selfeducation and the necessary methods, and information technology is a cognitive component.

The ability to plan and organize self-educational activities, fully own the methods of searching, collecting and processing information, set goals and find ways to solve self-educational problems in practice is an activity component.

The ability to make high demands on the results of one's actions, the ability to analyze, critically evaluate oneself, exercise self-control and self-assessment of one's activities characterizes the evaluative-reflective component of selfeducational competence

A pedagogical experiment showed that in the experimental group where the formative experiment was carried out, significant qualitative changes were noted, in contrast to the control group in which the formative experiment was not conducted, no significant changes were observed.

An analysis of the results of an experimental study indicates a trend in the positive dynamics of the development of self-educational competence of students using modern digital educational technologies, namely the Internet platform Google Classroom.

\section{REFERENCES}

[1] A. Bilyalova, A. Gaifutdinov, A. Akhemetshina, E. Tugusheva, Problems of Additional Vocational Education, International Conference on the Theory and Practice of Personality Formation in Modern Society (ICTPPFMS-18), Advances in Social Science, Education and Humanities Research, Vol.198, 2018, pp. 178-182. DOI: https://doi.org/10.2991/ictppfms18.2018 .31

[2] A. Bilyalova, D. Salimova, T. Zelenina, Digital Transformation in Education, ICIS 2019, LNNS 78, 2019, pp. 265-276.

[3] A. Sushkova, A.A. Bilyalova, D.D. Khairullina, Ch.R. Ziganshina, E-learning efficiency: linguistic subject taught via electronic educational resources, The 2019 International Conference on Digital Science, Advances in Intelligent Systems and Computing, Vol.1114, 2020, pp. 197-206.

[4] D. Carlson, Respondent: Self education-identity, self, and the new politics of education, Power/Knowledge/Pedagogy: The Meaning of Democratic Education in Unsettling Times, 2018, pp. 191-200. DOI: https://doi.org/10.4324/9780429498060

[5] C. Levy, Education and self-education: Staffing the early ilp, Socialism and the Intelligentsia 1880-1914, 3, 2016, pp. 135-210. DOI: https://doi.org/10.4324/9781315564128

[6] Kritskaya, A.R. Some conceptual bases of selfeducation of students [Nekotorye kontseptual'nye osnovy samoobrazovaniia obuchaiushchikhsia] Voprosy Filosofii, (5), 2013, pp. 70-74.

[7] M. De Fátima Morgado Cortez Batista, L.G. Elliot, Self-education evaluation: Construction and validation of instrument for the montessorian teacher [Avaliação da Autoeducação: Construção e Validação de Instrumento para o Professor Montessoriano], Meta: Avaliacao, 6 (17), 2014, pp. 176-198.

[8] A. Dobrijevic, P. Krstic, Self-education and university, Synthesis Philosophica, 28 (1-2), 2014, pp. 83-96.

[9] R. Sagitova, Students' self-education: learning to learn across the lifespan, ERPA International Congress on Education, Procedia Social and Behavioral Sciences, Vol.152, 2014, pp. 272-277. 
[10] A. Kozerska, Self-education of students of pedagogy and their social roles, New Educational Review, 27 (1), 2012, pp. 78-89.

[11] L. Zhimin, On the Key Points in the Construction of Education and Self-education Classroom System, 4th International Conference on Education Technology, Management and Humanities Science (ETMHS), Advances in Social Science Education and Humanities Research, Vol. 194, 2018, pp. 6-11.

[12] P. Fairfield, Self-Education, Teachability and learnability: Can thinking be taught? Routledge International Studies in the Philosophy of Education, Vol. 40, 2017, pp. 120-143.

[13] S. Striguna, Essence of self-education competence in pedagogy, Society, Integration, Education, Vol. 1, 2015, pp. 405-414

[14] E. Gilyazeva, O. Evgrafova, N. Sharypova, R. Akhunzianova, "Flipped Classroom" Technology in Teaching Foreign Languages // DSIC'19 - The 2019 International Conference on Digital Science, Advances in Intelligent Systems and Computing, Volume 1114 AISC, 2020, Pages 229-240. DOI: https://doi.org/10.1007/978-3-030-37737-3_21

[15] M.I. Podnebesova Essential characteristics of selfeducational competence [Sushchnostnye harakteristiki samoobrazovatel'noj kompetentnosti], Scientific electronic archive. URL: http://econf.rae.ru/article/7457

[16] E.S. Chebotareva, Self-educational competence of future specialists as a criterion of their quality of training [Samoobrazovatel'naya kompetentnost' budushchih specialistov kak kriterij ego kachestva podgotovki], Uchenye zapiski: elektronn. nauch. zhurnal Kurskogo gos. un-ta. Kursk. URL: http://www.scientific-notes.ru

[17] I.D. Ibragimov, K.V. Ilkevich, N.E. Erofeeva, N.S. Sakharova, N.M. Minyaeva, L.P. Ovchinnikova, Students self-work organization: educational activity self-regulation's technological aspect, Man in India, No97(14), 2017, pp. 85-102. 